\title{
Ecotoxicological evaluation of the application of landfill leachate on the germination of cabbage (Brassica oleracea var. capitata)
}

\author{
Heider Alves Franco ${ }^{1}$, Monica Regina da Costa Marques², Gabrielle Marjory de Oliveira \\ Martins $^{3}$, Yasmin Laureano Mussel ${ }^{4}$, Sérgio Thode Filho ${ }^{5}$ \\ ${ }^{1}$ Professor at the Federal Institute of Education, Science and Technology of Rio de Janeiro - IFRJ, Campus Pinheiral, RJ, \\ Multidisciplinary Laboratory of Agro-Environmental Technology - LAMTAA. heider.franco@ifrj.edu.br \\ ${ }^{2}$ Professor at the State University of Rio de Janeiro - UERJ, Environmental Technology Laboratory - LABTAM \\ ${ }^{3}$ Student of the Technical Course in Environment - IFRJ, Campus Pinheiral, RJ, Multidisciplinary Laboratory of Agro- \\ Environmental Technology - LAMTAA \\ ${ }^{4}$ Student of the Technical Course in Environment - IFRJ, Campus Pinheiral, RJ, Multidisciplinary Laboratory of Agro- \\ Environmental Technology - LAMTAA \\ ${ }^{1}$ Professor at the Federal Institute of Education, Science and Technology of Rio de Janeiro - IFRJ, Campus Duque de \\ Caxias, RJ, Multidisciplinary Laboratory Waste Management - LMGR
}

\begin{abstract}
In sanitary landfills occurs the disposal of varied variety of residues that lead to the formation of leachate generated from the decomposition of urban solid wastes. Special attention should be given to leachate, as it may affect natural resources. The adoption of ecotoxicity tests may contribute to understand the relationship of pollutant with the environment in case of disposal or spillage. Thus, germination trials with cabbage (Brassica oleracea var. capitata) submitted to different dosages of landfill leachate $(3.125 \%, 6.25 \%, 12.5 \%, 25 \%, 50 \%$ and $100 \%)$ were proposed in two substrates: paper filter and soil. The objective of this work was to evaluate the direct and indirect impact of the leachate on the germination of cabbage seeds, through the LC50 and the values of NOEC and LOEC. In both substrates it was not possible to determine the LC50 from the doses tested. In the paper test, the determination of LOEC, occurred with treatment $3.125 \%$. For the soil test, the LOEC value is obtained with the $50 \%$ dose. The species presents a high potential for ecotoxicity bioassays to determine environmental impact, due to its sensitivity to variations in the environment.
\end{abstract}

Keywords: Landfill leachate. Environmental impact. Lethal Concentration. Bioassays.

\section{Introduction}

In sanitary landfills, the disposal of the different wastes occurs specially as urban solid waste (USW). These are characterized by a complex mixture of materials constituted by organic matter (paper, cardboard, wood branches) and inert materials (plastics, glass, metal, etc.) (CARVALHO et al., 2006). 
Such residues when disposed in the medium without proper preparation for packaging, present potential as polluting materials. Additionally, the significance of the impact of solid waste also depends on the composition of those residues that may change according to environmental conditions, urbanization and the socioeconomic level of the generating region, as well as the type of waste management (GIORDANO, BARBOSA FILHO and CARVALHO, 2011).

This feature makes the USW decomposition process extremely complex due to the formation of leachate. Special attention should be given to the leachate generated in the landfills, as it presents a potentially polluting liquid that can attack nearby natural resources, if not treated and discarded in a careful and controlled manner (SALEM et al., 2008).

The generation of leachate occurs due to the degradation of solid residues by the presence of microorganisms, most of them bacteria acting on aerobic or anaerobic metabolism, characterized by the existence and absence of oxygen, respectively; besides these, the conditions of the medium, characteristic of the residues and precipitation contribute to produce a larger or smaller volume of leachate (IPT, 1995).

For landfill leachates, several treatment methods have already been studied, Omar and Rohani (2015) discussed a broad review on the subject, presenting methodology, advantages and disadvantages. According to the authors, there is a need to expand knowledge in all aspects about landfills.

The characterization of landfill leachate identifies and quantifies the chemical substances and physical characteristics of the landfill; however, it is not possible to infer its direct impact on the ecosystem. To analyze the toxic effects of substances or mixtures, discarded / disposed of and / or to be used in human activities, toxicity tests or bioassays must be carried out to predict the potential impact of a xenobiotic (toxic agent) on the environment (FLOHR et al., 2005).

These laboratory tests were carried out under specific and controlled experimental conditions, aiming to estimate the toxicity of substances, agricultural, industrial and domestic effluents, medicines, chemicals in general and environmental samples (water or sediments), as well as evaluating the resulting synergistic and antagonistic effects (COSTA, et al., 2008).

For this purpose, ecotoxicity tests are executed on different test organisms. Germination tests are performed to determine the potential effect of a pollutant. To determine the concentration / lethal dose capable of causing death or inhibition in 50\% of test organisms (LC50), it is also possible to determine the lowest concentration where the pollutant effect is observed (LOEC), as well as higher concentration in which no deleterious effect is observed (NOEC) (ADAMS et al., 2002; RONCO; BAEZ and GRANADOS, 2004).

The Organization for Economic Cooperation and Development (OECD) publishes a list of species for this type of trial, and one of them is cabbage (Brassica oleracea var. capitata) (OECD, 2003).

Therefore, the present work aims to determine the impact potential of landfill leachate on the germination and development of roots and aerial part of cabbage (Brassica oleracea var. capitata). 


\section{Material and methods}

\subsection{Materials}

The tests took place in the Multidisciplinary Laboratory for Agro-environmental Technology of the Pinheiral Campus of the Federal Institute of Rio de Janeiro, located in the municipality of Pinheiral, Rio de Janeiro state.

The landfill leachate used in the study was provided by the company Haztec Tecnologia e Planejamento Ambiental S.A., which manages the Waste Treatment Center (WTC) located in the city of Barra Mansa, with geographic coordinates $22^{\circ} 35^{\prime} 11.52^{\prime \prime S}$ and $44^{\circ} 12^{\prime} 54.31^{\prime \prime} \mathrm{W}$.

The planning, compilation and maintenance of the leachate were performed according to NBR 9897 (ABNT, 1987). The leachate was stored in a plastic container with 50 liter capacity and 25\% of its contents were renewed monthly to avoid losing its characteristics.

We used seeds of lettuce (Lactuca sativa L.) cv. Baba, from the company Isla seeds, whose germination potential was around $95 \%$.

Petri dish $(9.5 \mathrm{~cm}$ diameter) and substrate qualitative filter paper $(1 \mu \mathrm{m}$ porosity) were used for direct impact testing. For the indirect impact test, the substrate used was a Planosol Hapless $\mathrm{Tb}$ Eutrophic of sandy texture.

The environmental conditions for both assays were: temperature $\left(25 \pm 2{ }^{\circ} \mathrm{C}\right)$ (BRASIL, 2009); photoperiod (12 hours light / 12 hours dark) and total run time of 120 hours (LINDER et al., 1989). These conditions were obtained with the use of a Thelga TF34 BOD chamber, where the container dishes were prepared.

\subsection{Methods}

\subsubsection{Physical and chemical characteristics of landfill leachate.}

The physicochemical characterization was performed according to the method of the American Public Health Association (APHA, 2005). The following parameters were characterized: electrical conductivity (EC), $\mathrm{pH}$ and total dissolved solids (TDS), through direct reading of a waterproof multiparameter PCS Testr 35; and chemical oxygen demand (COD) using the closed reflux colorimetric method of digestion of the samples with a Tecnal TE-021 dry block digester, followed by reading the samples in a Hach DR 5000 spectrophotometer.

The determination of cations and anions was performed by ion chromatography. Samples of landfill leachate were diluted 1000 times and then filtered with syringes coupled to fiberglass filters with $0.22 \mu \mathrm{m}$ pore size to avoid clogging. The filtered material was placed in vials of a Dionex ICs 3000 ion chromatography system. The apparatus was equipped with an IonPac CS16 analytical column $(3.0 \times 250 \mathrm{~mm})$ preceded by two pre-columns. The cation suppressor used was 300 CSRS $(2.0 \mathrm{~mm})$. The equipment also has an IonPac AS 23 analytical column $(2.0 \times 250 \mathrm{~mm})$ preceded by a guard column and an anion suppressor (SRS $2 \mathrm{~mm}$ ). In the mobile phase testing, the cations used for detection were methyl sulfonic acid (MSA) injected into the column at a concentration of $32 \mathrm{mmol} \mathrm{L}^{-1}$. For anions, we used solutions of carbonate/sodium bicarbonate at concentrations of $4.5 \mathrm{mmol} \mathrm{L}^{-1}$ and $0.8 \mathrm{mmol} \mathrm{L}^{-1}$.

For determination of the metal concentrations ( $\mathrm{Al}, \mathrm{Cd}, \mathrm{Cr}, \mathrm{Cu}, \mathrm{Fe}, \mathrm{Mn}, \mathrm{Ni}, \mathrm{Pb}$ and $\mathrm{Zn}$ ), samples were digested according to the USEPA procedure (1998): $20.0 \mathrm{~mL}$ of sample and $10.0 \mathrm{~mL}$ of nitric acid $\left(\mathrm{HNO}_{3}\right)$ PA were placed in a Teflon bottle which was then closed and heated in a microwave 
oven (Milestone Start E) with a power of $600 \mathrm{~W}$ for $20 \mathrm{~min}$ (heating to $170{ }^{\circ} \mathrm{C}$ for 10 minutes and maintained at $170{ }^{\circ} \mathrm{C}$ for 10 minutes). The product obtained was passed through filter paper and swelled in $100 \mathrm{~mL}$ flat-bottom volumetric flasks. Samples were measured in duplicate with a Varian 240 ASA flame atomic absorption spectrometer. The operating conditions used in the FAAS were exposure time of 5 minutes, air-acetylene flame; airflow of $10.0 \mathrm{~L} \mathrm{~min}^{-1}$, and acetylene flow of $2.0 \mathrm{~L} \mathrm{~min}^{-1}$.

\subsubsection{Effect on germination and development of cabbage (Brassica oleracae var. capitata) roots - direct impact.}

The experimental dynamics followed a completely randomized design developed in two groups: test and control. For the test group, six treatments were applied with increasing doses in a ratio of 50\% of landfill leachate, as follows (ARAGÃO et al., 2008 ALMEIDA et al., 2011.): T1 = $3.125 \%$ leachate $+96.875 \%$ deionized water; $\mathrm{T} 2=6.25 \%$ leachate $+93.75 \%$ deionized water; $\mathrm{T} 3=$ $12.5 \%$ leachate $+87.5 \%$ deionized water; $\mathrm{T} 4=25 \%$ leachate $+75 \%$ deionized water; $\mathrm{T} 5=50 \%$ leachate $+50 \%$ deionized water; T6 $=100 \%$ leachate; and control (TC) $=100 \%$ deionized water. All treatments were performed in triplicate.

In the study, 20 seeds of cabbage were divided in Petri dishes $(9.5 \mathrm{~cm}$ in diameter) with qualitative filter paper substrate (porosity $14 \mu \mathrm{m}$ ) and moistened with $4.0 \mathrm{~mL}$ of the sample solutions. To ensure moisture throughout the test, Petri dishes were wrapped with transparent parafilm and placed in a germination chamber.

\subsubsection{Effect on germination and development of Cabbage (Brassica oleracae var. capitata) - indirect impact.}

For this assay the methodology of LOPES et al (2010) was adapted, $50 \mathrm{~mL}$ plastic containers were filled with $50 \mathrm{~g}$ of sandy soil moistened with $13.5 \mathrm{~mL}$ of solution (landfill leachate + deionized water), according to the treatments applied in the direct impact test. Afterwards, ten lettuce seeds were distributed on the soil at equal distances. Soon after sowing, the plastic containers were covered with parafilm (to minimize possible losses of humidity and incubated in a germination chamber, BOD type.

The soil used in the test was physico-chemically characterized according to the method recommended by the Brazilian Agricultural Research Corporation - EMBRAPA (1997) (Table 2).

\subsection{Evaluation and Statistical Analysis.}

At the end of the experimental period the following parameters were evaluated: number of seeds germinated and not germinated, and length of roots (USEPA, 1996; OECD, 2003). The root length was measured with a digital caliper.

Seeds showing a radicle protrusion were germinated (SOBRERO and RONCO, 2004). We considered valid the tests for germination in the control (deionized water) that presented germination rate greater than $80 \%$ (BRASIL, 2009).

For the determination of lethal effects in both tests, the LC50 was identified from comparison of the mean germination and/or graphical analysis.

The sub-lethal effects were determined by the no observed effect concentration (NOEC), which corresponds to the highest concentration/dose of toxicant that causes no statistically 
significant deleterious effect on the organisms during the exposure time under the test conditions; also, the lowest observed effect concentration (LOEC), which is the lowest concentration/dose of toxicant that causes statistically significant deleterious effect on the organisms during the exposure time and test conditions (RONCO et al., 2004). NOEC and LOEC were determined by comparison between the average length of the roots.

After physical examination and with the means values of variables, we assessed for Lilliefors test of normality and Cochran-Bartlett test to ensure homogeneity. The Scott-Knott test was used to analyze the significance between treatments at $5 \%$ probability. To determine the correlation between the parameters and concentration of pollutant (landfill leachate), we used Pearson correlation coefficient $(r)$ and t-test for significance at $\mathrm{p}<0.05$ (ACHEN, 1977; ALDRICH, 1995).

The analyzes were carried out with Assistat 7.7 (SILVA \& AZEVEDO, 2016), and graphs plotted using Microsoft Excel 2013.

\section{Results and discussion}

The physical-chemical parameters presented in Table 1 allow to classify landfill leachate as a young leachate (KURNIAWAN et al., 2010). It is also observed that when these parameters are compared with the effluent quality standard for release according to CONAMA resolution 430/2011, this crude leachate does not have characteristics that allow its arrangement in the receiving body, as a potential pollutant from a physical-chemical perspective. Also, the parameters salinity, aluminum and sodium present high values. Studies on aluminum toxicity demonstrate the deleterious effects of this cation on plant metabolism (KOCHIAN, 2004). The exchangeable aluminum of the soils, for example, can reduce the germination, exerting decisive influences on the metabolism of seeds (CRUZ et al., 1995).

Table 1. Physico-chemical characterization of Barra Mansa-RJ's CTR landfill leachate.

\begin{tabular}{|c|c|c|c|}
\hline \multirow{2}{*}{ Evaluated parameters } & \multirow{2}{*}{ Unit } & \multirow{2}{*}{$\begin{array}{c}\text { Observed } \\
\text { values }\end{array}$} & \multirow{2}{*}{$\begin{array}{c}\text { CONAMA } 430 \\
\text { Effluent discharge }\end{array}$} \\
\hline & & & \\
\hline pH (water) & ------- & 9.0 & $5.0-9.0$ \\
\hline Conductivity & $\mathrm{d} S \mathrm{~m}^{-1}$ & 33.3 & N.D. \\
\hline COD & $\mathrm{mg} \mathrm{L}^{-1}$ & 5592 & 120 \\
\hline Total dissolved solids & $\mathrm{mg} \mathrm{L}^{-1}$ & 23600 & N.D. \\
\hline Salinity & $\mathrm{mg} \mathrm{L}^{-1}$ & 16900 & N.D. \\
\hline Aluminium* & $\mathrm{mg} \mathrm{L}^{-1}$ & 7625 & N.D. \\
\hline Ammonium ${ }^{* *}$ & $\mathrm{mg} \mathrm{L}^{-1}$ & 595.27 & 20.0 \\
\hline Cadmium* & $\mathrm{mg} \mathrm{L}^{-1}$ & 0.025 & 0.2 \\
\hline Calcium $^{* *}$ & $\mathrm{mg} \mathrm{L}^{-1}$ & 95.38 & N.D. \\
\hline Lead $^{*}$ & $\mathrm{mg} \mathrm{L}^{-1}$ & 0.37 & 0.5 \\
\hline Chloride ${ }^{* *}$ & $\mathrm{mg} \mathrm{L}^{-1}$ & 857.50 & 250 \\
\hline Copper* & $\mathrm{mg} \mathrm{L}^{-1}$ & 0.17 & 1.0 \\
\hline Iron ${ }^{*}$ & $\mathrm{mg} \mathrm{L}^{-1}$ & 13.66 & 15.0 \\
\hline Lithium $^{* *}$ & $\mathrm{mg} \mathrm{L}^{-1}$ & 15.22 & 2.5 \\
\hline Magnesium* & $\mathrm{mg} \mathrm{L}^{-1}$ & 15.37 & N.D. \\
\hline Manganese* & $\mathrm{mg} \mathrm{L}^{-1}$ & 0.31 & 1.0 \\
\hline Niquel $^{*}$ & $\mathrm{mg} \mathrm{L}^{-1}$ & 0.48 & 2.0 \\
\hline Nitrate $^{* *}$ & $\mathrm{mg} \mathrm{L}^{-1}$ & 496.75 & 10 \\
\hline Potassium** & $\mathrm{mg} \mathrm{L}^{-1}$ & 694.46 & N.D. \\
\hline Sodium ${ }^{* *}$ & $\mathrm{mg} \mathrm{L}^{-1}$ & 1172.46 & N.D. \\
\hline
\end{tabular}




\begin{tabular}{|c|c|c|c|}
\hline Sulfate ${ }^{* *}$ & $\mathrm{mg} \mathrm{L}^{-1}$ & 846.00 & 250 \\
\hline Zinc $^{*}$ & $\mathrm{mg} \mathrm{L}^{-1}$ & 1.13 & 5.0 \\
\hline
\end{tabular}

It is observed (Table 2) that the $\mathrm{Al}^{3+}$ element, known by its phytotoxicity, was not detected in the analysis. The $\mathrm{pH}$ value (7.50) is close to neutrality. Such characteristic allows the availability of the nutrients present in the soil.

Table 2: Physico-chemical characteristics of soil.

\begin{tabular}{|c|c|c|c|c|c|c|c|c|c|c|c|}
\hline $\mathrm{pH}$ & $\mathrm{Ca}^{2+}$ & $\mathrm{Mg}^{2+}$ & $\mathbf{K}^{+}$ & $\mathrm{Na}^{+}$ & $S$ & $\mathrm{Al}^{3+}$ & $\mathrm{H}^{+}+\mathrm{Al}^{3+}$ & $\mathrm{T}$ & $\mathbf{P}$ & $\mathbf{V}$ & C.org. \\
\hline $\mathrm{H}_{2} \mathrm{O}$ & $-y_{1}$ & 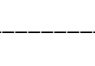 & - & $--\mathrm{cm}$ & $l_{c} d m$ & & & & $--\mathrm{mg} \mathrm{dm}^{-3}$ & --_-_o & \\
\hline 7.50 & 5.80 & 0.64 & 0.05 & 0.03 & 6.52 & 0.00 & 1.16 & 7.68 & 320.79 & 84.96 & 0.95 \\
\hline
\end{tabular}

$\overline{\mathrm{S}}$ - sum of bases $(\mathrm{S}=\mathrm{Ca}+\mathrm{Mg}+\mathrm{Na}+\mathrm{K}+\mathrm{Al}) ;\left(\mathrm{H}^{+}+\mathrm{Al}^{3+}\right)-$ potential acidity; $\mathrm{T}-$ Value $\mathrm{T}(\mathrm{T}=\mathrm{S}+(\mathrm{H}+\mathrm{Al})) ; \mathrm{V} \%$ - base saturation $(\mathrm{V}(\%)=(\mathrm{S} \times 100) / \mathrm{T}) ; \mathrm{C}=$ organic carbon.

The analyzes carried out in the soil (Table 2) for the indirect impact test show that its physicochemical characteristics that guarantee an adequate environment for the development of the study. Also, assuring that any changes in the characteristics of the species do not occur due to soil influence.

Comparing the data of Table 1, with the parameters studied for the species, it is observed that the introduction of landfill leachate exerts a great influence. The mean values of the percentage of germination as a function of the different doses of landfill leachate are shown in Figure 1. Significant differences between treatments were observed by Tukey's test $(p<0.05)$. 


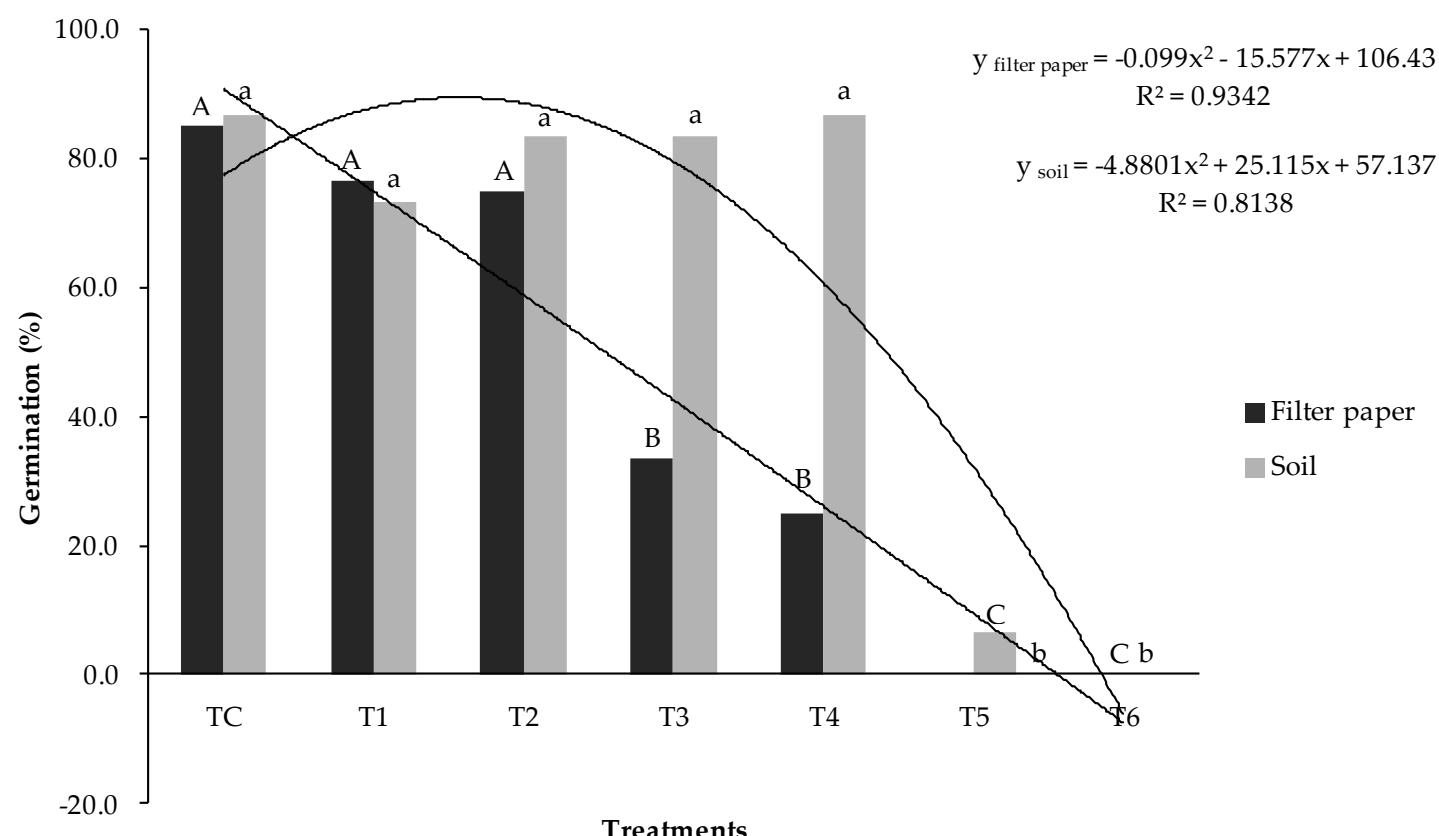

Figure 1: Average germination percentage $(\mathrm{G} \%)$ of Cabbage submitted to the application of different doses of landfill leachate in two substrates, filter paper and soil. (Means followed by the same capital letter and the same lowercase letter do not differ by the Tukey test at $5 \%$ probability. TC = deionized water control; T1 = leachate dose of $3.125 \%$; T2 = leachate dose of $6.25 \%$; T3 = leachate dose: $12.5 \%$; T4 = leachate dose of $25 \%$; T5 = leachate dose of $50 \%$; and T6 = leachate dose of $100 \%$ ).

From the doses tested in both trials it was not possible to determine the LC50 of the leachate in relation to the cabbage. The evaluation of germination shows that in the direct impact test, whose substrate was filter paper, the limit dose for cabbage is obtained in the treatment with $6.25 \%$ (T2). Thus, the germination of the species is reduced in such a way that inhibition reaches approximately $61 \%$ in relation to the control treatment.

For the soil test, germination behavior describes a divergent result in relation to filter paper test. It is also observed (Figure 1) that there is only significant difference in the treatments, from $25 \%$ of leachate (T4). This difference configures an inhibition of approximately $100 \%$ in the germination in relation to the control treatment.

FRANCO et al. (2017) evaluated the effect of landfill leachate on the germination of lettuce (Lactuca sativa L.) seeds on filter paper and soil, identifying significant differences in the parameter from $12.5 \%$ and $25 \%$, respectively. These results corroborate with those obtained in the present study in relation to the soil substrate. However, it is observed that on filter paper the cabbage was less tolerant to the leachate in relation to the lettuce.

The germination process can be influenced by intrinsic and extrinsic factors to the seed. Among the intrinsic factors, special emphasis is given to the viability of the embryo and dormancy, which for cabbage is not a limiting factor. Amongst the extrinsic factors, environmental conditions have the main influence, where the presence of a potentially toxic substancelimits the process (AYERS, 1952; SANTOS et al., 1992).

Considering the high salinity of the landfill leachate, CE $>2.25 \mathrm{dS} \mathrm{m}^{-1}$ (RICHARDS, 1980), it can be stated that this characteristic associated with the presence of other components, such as aluminum, in the pollutant may have presented toxic potential to germination of cabbage. 
Santos et al. (2016) state that salinity-tolerant plants exhibit selective ion absorption meaning that these plants can remove essential nutrients from the saline solution, where the concentration of non-essential ions is greater to regulate osmotic stress.

The evaluation of cabbage root length was used to determine the sublethal effect of landfill leachate. Mean values of the radicle length as a function of the different doses of landfill leachate are shown in Figure 2. Significant differences between treatments were observed by Tukey's test $(\mathrm{p}<0.05)$.

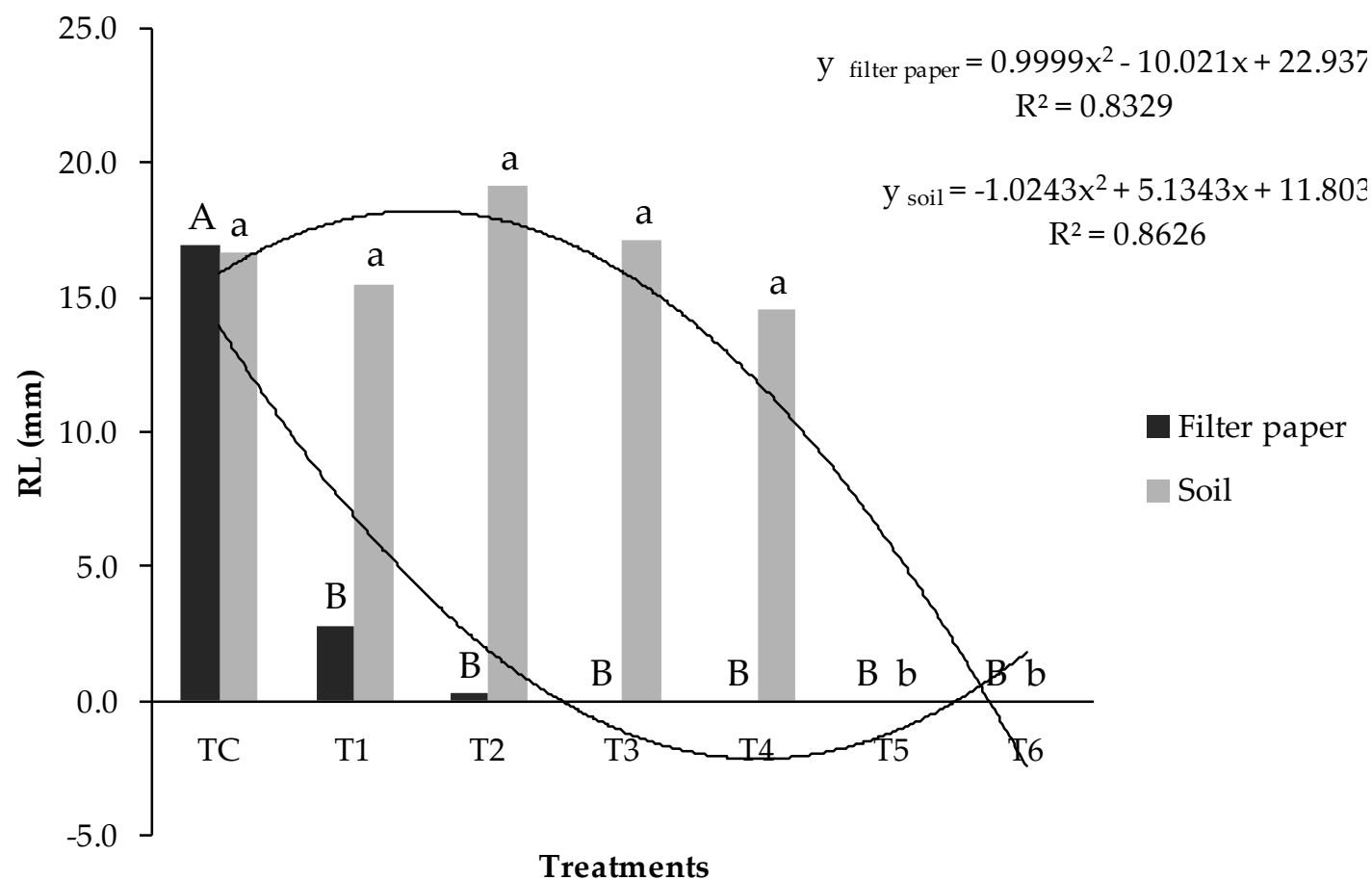

Figure 2: Average of radicle elongation of cabbage submitted to the application of different doses of landfill leachate in two substrates, filter paper and soil. (Means followed by the same capital letter and the same lowercase letter do not differ by the Tukey test at $5 \%$ probability. TC $=$ deionized water control; $\mathrm{T} 1=$ leachate dose of $3.125 \%$; T2 = leachate dose of $6.25 \%$; T3 = leachate dose: $12.5 \%$; T4 = leachate dose of $25 \%$; T5 = leachate dose of $50 \%$; and T6 = leachate dose of $100 \%$ ).

The analysis of the results (Figure 2), with filter paper as substrate, allows to identify significant effect in the lowest dose of leachate (treatment 3.125\%) when compared to the control treatment. The treatment promoted a reduction of approximately $84 \%$. It can be stated that the treatment $3.125 \%$ corresponds to the value of LOEC, concentration or dose of observed effect. It was not possible to determine the dose equivalent to NOEC from the treatments studied.

For the test whose substrate was sandy soil (Figure 2), we observed a similar behavior to the germination analysis. that is, there is no significant difference between the first three treatments of the test group in relation to the control group. It is further stated that from the $25 \%$ dose, complete inhibition of root growth occurs. Nevertheless, the said treatment can be defined as the dose that corresponds to the NOEC value and the treatment $50 \%$ as the dose equivalent to LOEC.

These results corroborate with those obtained by FRANCO et al. (2017) that evaluated the effect of landfill leachate on lettuce radicle length (Lactuca sativa L.) on filter paper and soil, and identified the LOEC values at $3.125 \%$ and $50 \%$, respectively. 
The effect of salinity most easily observed on plants is the reduction in growth due to nutritional imbalances (FERREIRA et al., 2001, NASCIMENTO et al., 2011 ).

The situation known as salinity is a soil that has excessive soluble salts, exchangeable sodium or both affecting plant development (RIBEIRO et al., 2009). The excess of sodium salts, for example, causes a generalized reduction of plant growth (CAVALCANTE et al., 2011).

The mean values of the hypocotyl length as a function of the different doses of landfill leachate are shown in Figure 3. Significant differences between treatments were observed by Tukey's test $(p<0.05)$.

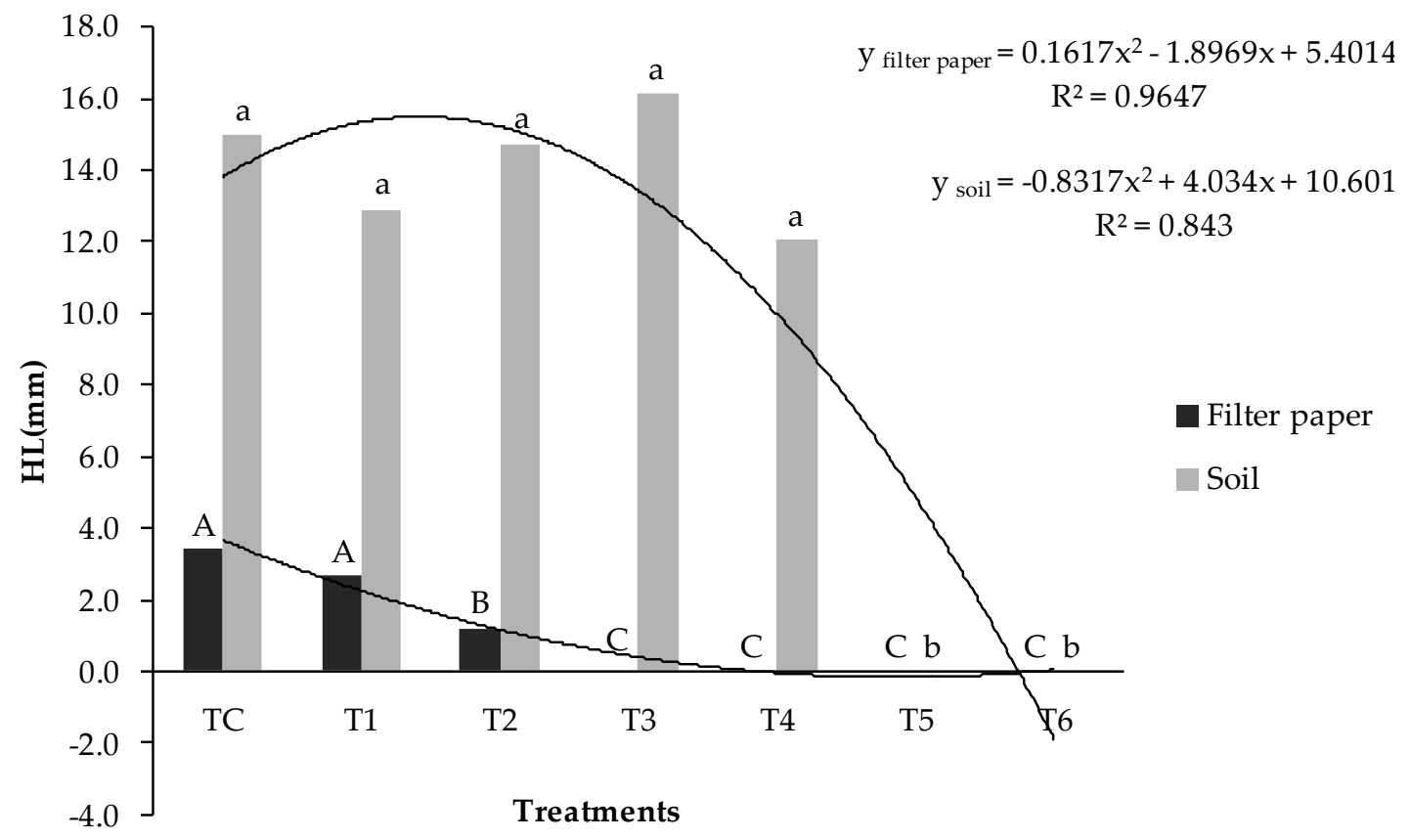

Figure 3: Average of hypocotyl elongation (HL) of cabbage submitted to the application of different doses of landfill leachate in two substrates, filter paper and soil. (Means followed by the same capital letter and the same lowercase letter do not differ by the Tukey test at $5 \%$ probability. TC $=$ deionized water control; $\mathrm{T} 1=$ leachate dose of $3.125 \% ; \mathrm{T} 2=$ leachate dose of $6.25 \% ; \mathrm{T} 3=$ leachate dose: $12.5 \%$; $\mathrm{T} 4=$ leachate dose of $25 \%$; $\mathrm{T} 5=$ leachate dose of $50 \%$; and $\mathrm{T} 6=$ leachate dose of $100 \%$ ).

Also considering the vegetative behavior of the cabbage in the test with filter paper, the evaluation of the length of the hypocotyl together with the root length confirms the significant negative influence of the landfill leachate. However, it occurs from the dose $3.125 \%$. It can be stated, according to the literature, that greater effect is due to the high salinity of the pollutant.

The values obtained for the length parameter of the hy pocotyl in the test whose substrate was the sandy soil, confirm the data obtained for the growth of the radicle and the germination, in such a way that only a significant difference in the parameter occurs for the $25 \%$ treatment.

The adverse effect observed in the present study is potentially due to the high salinity of the pollutant., Besides that, the difficulty to absorb water and the presence of other elements can configure levels that cause toxicity to the seeds (FRANCO et al., 2017).

\section{Conclusions}


The toxicity bioassay using cabbage seeds as a test organism is presented as a low-cost methodology, easy and fast execution and high sensitivity for the verification of the impact of landfill leachate.

In both trials it was not possible to determine the LC50 from the doses tested, although it is observed that the filter paper test was more restrictive, since $6.25 \%$ treatment was presented as a limit dose where from germination inhibition occurs. However, it was observed that the sublethal effects (LOEC) for the pollutant occur in dose 3.125\%.

The results were more flexible in relation to the introduction of the pollutant for the germination test in soil, since LOEC was obtained with the treatment corresponding to the 50\% dilution, which also defines the maximum dosage that no significant change in seed germination is observed.

\section{References}

ACHEN, Christopher H. Measuring Representation: Perils of the Correlation Coefficient. American Journal of Political Science. 1977; 21 (4): 805-815.

ADAMS, W.J.; ROWLAND, C.D. Aquatic toxicology Test Methods. In HOFFMAN, D.J; RATTNER, B.A.; BURTON Jr, G.A.; CAIRNS Jr, J. (Editores) Handbook of Ecotoxicology, Washington, D.C.: Lewis Publishers. 2.ed. p. 32 - 58, 2002.

ALDRICH, John H. Correlations Genuine and Spurious in Pearson and Yule. Statistical Science. 1995; 10 (4): 364-376.

ALMEIDA, C.; FERREIRA, D.; SECO, F.; IRIA, I. e JESUS, J. Análise Ecotoxicológica de Águas Residuais de Uma Indústria Metalúrgica. XI CNEA - Congresso Nacional de Engenharia do Ambiente. Lisboa, 2011.

APHA. AMERICAN PUBLIC HEALTH ASSOCIATION. Standard methods for examination of water and wastewater. Washington: American Water Works Association, 21th ed. $1.368 \mathrm{p}$. 2005.

ARAGÃO, M. A.; ARAÚJO, R. P. A. Métodos de ensaios de toxicidade com organismos aquáticos. In ZAGATTO, P.A.; BERTOLETTI, E. (Editores). Ecotoxicologia Aquática: Princípios e Aplicações, São Carlos, São Paulo: RIMA, 2008. P. 117 - 147.

ASSOCIAÇÃO BRASILEIRA DE NORMAS TÉCNICAS - ABNT. NBR 9897: Planejamento de amostragem de efluentes líquidos e corpos receptores - Procedimento. NBR - 9897/87. Rio de Janeiro, 22p. 1987.

AYERS, R. S.; WESTCOT, D. W. A qualidade da água na agricultura. Campina Grande, UFPB, 1999. 153p.

BRASIL. Ministério da Agricultura, Pecuária e Abastecimento. Regras para análise de sementes / Ministério da Agricultura, Pecuária e Abastecimento. Secretaria de Defesa Agropecuária. Brasília : Mapa/ACS, 2009. 399 p.

CARVALHO, A. L.; MATOS, A. T.; HAMAKAWA, P. J.; AZEVEDO, R. F. Produção de percolado por resíduos sólidos urbanos de diferentes idades, na presença de resíduos da construção civil e sob recirculação. Engenharia na Agricultura, v.14, n.2, p.131-138, 2006. 
CAVALCANTE, L. F.; CORDEIRO, J. C.; NASCIMENTO, J. A. M.; CAVALCANTE, Í. H. L.; DIAS, T. J. Fontes e níveis da salinidade da água na formação de mudas de mamoeiro cv. Sunrise solo. Semina: Ciências Agrárias, v.31, p.12811290, 2011.

CONAMA - Conselho Nacional do Meio Ambiente. Resolução n: 430/2011, de 13/05/2011. Disponível em: http://www.mma.gov.br/port/conama/legiabre.cfm?codlegi=646. Acesso em 10 Jul. 2017.

COSTA, C. R.; OLIVI, P.; BOTTA, C. M.; ESPINDOLA. E. L. G. A toxicidade em ambientes aquáticos: discussão e métodos de avaliação. Quim Nova. 31 : 1820-1830, 2008.

CRUZ, M.S.; PÉREZ-URRIA, E.; MARTIN, L.; AVALOS, A.; VICENTE, C. Factors affecting germination of Canavalia brasiensis, Leucena loucocephala, Clitoria ternata and Calopogonio mucunoides seeds. Seed Science \& Technology, Zurich, v.23, n.2, p.447-454, 1995.

EMBRAPA - EMPRESA BRASILEIRA DE PESQUISA AGROPECUÁRIA. Manual de métodos de análises de solos. Rio de Janeiro: Embrapa-CNPS. 1997. 212p

FERREIRA, R. G.; TÁVORA, J. A. F.; HERNANDEZ, F. F. F.. Distribuição da matéria seca e composição química das raízes, caule e folhas de goiabeira submetida a estresse salino. Pesquisa Agropecuária Brasileira, v. 36, n. 1, p. 79-88, 2001.

FLOHR, L.; BRENTANO, D.M.; CARVALHO-PINTO, C.R.S.; MACHADO, V.G. \& MATIAS, W.G. Classificação de resíduos sólidos industriais com base em testes ecotoxicológicos utilizando Daphnia magna: Uma alternativa. Biotemas, 18:7-18, 2005.

FRANCO, H.A.; MARQUES, M.R. da C.; BRAGA, C.F.; IZIDORIO, A. de S.; THODE-FILHO, S. Effect of landfill leachate on germination of lettuce seeds (Lactuca sativa L.). Electronic Journal of Management, Education and Environmental Technology-REGET, (2017). [no prelo]

GIORDANO, G.; BARBOSA FILHO, O.; CARVALHO, R. J. Processos físico-químicos para tratamento do chorume de aterros de resíduos sólidos urbanos. Rio de Janeiro: COAMB / FEN / UERJ, Série Temática: Tecnologias Ambientais - Volume 4, 178 p., 2011.

INSTITUTO DE PESQUISAS TECNOLÓGICAS DO ESTADO DE SÃO PAULO (IPT). Lixo Municipal: manual de gerenciamento integrado. São Paulo: IPT/CEMPRE. 1995. 278p.

KOCHIAN, L. V.; HOEKENGA, O. A.; PIÑEROS, M. A. How do crop plants tolerate acid soils? Mechanisms of aluminum tolerance and phosphorous efficiency. Annual Review of Plant Physiology and Molecular Biology, v.55, p. 459-493, 2004.

KURNIAWAN, T. A.; LO, W.; CHAN, G. SILLANPAA, M. E. T. Biological processes for treatment of landfill leachate. Journal of Environmental Monitoring, v. 12, p. 2032-2047, 2010. Disponível em: $<$ http://pubs.rsc.org/en/content/articlelanding/2010/em/c0em00076k\#!divAbstract $>$. Acesso em: 14 abr. 2017.

LINDER, G.; GREENE, J.; RATSCH, H.; NWOSU, J.; SMITH, S. AND WILBORN, D. Seed germination and root elongation toxicity tests in hazardous waste site evaluation: Methods development and applications. U.S. Environmental Protection Agency, Washington, D.C., EPA/600/D-89/109 (NTIS PB90113184), 1989. 
LOPES, P.R.M.; MONTAGNOLLI, R.N.; DOMINGUES, R.F.; BIDOIA, E.D. Toxicity and biodegradation in sandy soil contaminated by lubricant oils. Bull. Environ. Contam.Toxicol. 84 (4), 454-458. 2010.

NASCIMENTO, J. A. M.; CAVALCANTE, L. F.; SANTOS, P. D. dos; SILVA, S. A. da; VIEIRA, M. da S.; OLIVEIRA, A. P. de. Efeito da utilização de biofertilizante bovino na produção de mudas de pimentão irrigadas com água salina. Revista Brasileira Ciências Agrárias, v. 6, n. 2, p. 258264, 2011.

ORGANIZATION FOR ECONOMIC COOPERATION AND DEVELOPMENT - OECD Terrestrial Plant Test: 208: Seedling Emergence and Seedling Growth Test. Guideline for the Testing of Chemicals Proposal for Updating Guideline 208, 2003.

OMAR, H.; ROHANI, S. Treatment of landfill waste, leachate and landfill gas: A review. Front. Chem. Sci. Eng. 9(1): 15-32, 2015.

RIBEIRO, M. R.; BARROS, M. F. C.; FREIRE, M. B. G. S. Química dos solos salinos e sódicos. In: MELO, V. F.; ALLEONI, L. R. F. (Ed.). Química e mineralogia do solo, 1. ed. Viçosa, MG: SBCS, p.449-484. 2009.

RICHARDS, L.A. Diagnóstico y reabilitación de suelos salinos y sódicos. México: Editorial Limusa, 1980. 172p.

RONCO, A.; BÁEZ, M. C. D.; GRANADOS, Y. P. Em Ensayos Toxicológicos y Métodos de Evaluación de Calidad de Aguas - Estandarización, Intercalibración, Resultados y Aplicaciones; Morales, G. C., ed.; Centro Internacional de Investigaciones para el Desarrollo: Ottawa, 2004, cap. 1.

SALEM, Y.; HAMOURI, K., DJEMAA, R. and ALOIS, K. Evaluation of landfill leachate pollution and treatment. Desalination, 220, 108-114. 2008.

SANTOS, J. B.; GHEYI, H. R.; LIMA, G.S.; XAVIER, D.A.; CAVALCANTE, L.F.; CENTENO, C.R. M. Morfofisiologia e produção do algodoeiro herbáceo irrigado com águas salinas e adubado com nitrogênio. Comunicata Scientiae, v.7, n.1, p.86-96, 2016.

SANTOS, V.L.M.; CALIL, A.C.; RUIZ, H.A.; ALVARENGA, E.M.; SANTOS, C.M. Efeito do estresse salino e hídrico na germinação e vigor de sementes de soja. Revista Brasileira de Sementes, Pelotas, v. 14, n.2, p.189-194, 1992.

SILVA, F. de A. S.; AZEVEDO, C. A. V. de. The Assistat Software Version 7.7 and its use in the analysis of experimental data. Afr. J. Agric. Res, v.11, n.39, p.3733-3740, 2016. DOI: 10.5897/AJAR2016.11522.

SOBRERO, M. C.; RONCO, A. Ensayo de toxicidad aguda con semillas de lechuga (Lactuca sativa L.). In: Morales, G. C. Ensayos toxicológicos y métodos de evaluación de calidad de águas: Estandarización, Intercalibración, resultados e ya aplicaciones, IMTA, p. 63-72, 2004.

USEPA - UNITED STATES ENVIRONMENTAL PROTECTION AGENCY - US EPA - Seed Germination/ Root Elongation Toxicity Tests. Ecological Effects, Tests Guidelines, 1996. 
USEPA - UNITED STATES ENVIRONMENTAL PROTECTION AGENCY. SW-846 EPA Method 3051A. Microwave assisted acid digestion of sediments, sludges, soils and oils. Test Methods for Evaluating Solid Waste. 3rd Update. Washington, DC, 1998. 